\title{
Maraviroc in PML-IRIS
}

\section{A separate ball game under HIV infection and natalizumab?}

\section{OPEN}

Israel Steiner, $\mathrm{MD}$

Felix Benninger, MD

Correspondence to Dr. Steiner:

israels@ekmd.huji.ac.il

Neurol Neuroimmunol

Neuroinflamm

2017;4:e331; doi: 10.1212/

NXI.0000000000000331
Progressive multifocal leukoencephalpathy (PML) is a severe, often fatal, opportunistic infection of the CNS. First reported in 1958 as a white matter disorder in 3 patients with lymphoproliferative disorders, ${ }^{1}$ subsequent studies revealed a polyomavirus, named John Cunningham (JC) virus from the initials of the patient from whose brain it was initially isolated, as the causative agent. Despite previous reports, there is no evidence that PML is caused by either SV40 or BK virus. $^{2}$

The pathogen is a ubiquitous DNA virus that infects only humans. Subclinical infection often takes place within the first decade of life. Both the mechanism of infection and clinical expression of primary infection remain undefined. Initially, predominantly associated with lymphoproliferative disorders, with the AIDS pandemic, PML became strikingly prevalent, observed in $4 \%-5 \%$ of all patients with HIV prior to the availability of highly active antiretroviral therapy (HAART). The era of monoclonal antibodies for immune-mediated conditions such as natalizumab (Tysabri) for MS and Crohn disease and efalizumab (Raptiva) for psoriasis heralded another context for PML. As of November 30, 2016, there have been 698 reported cases of PML under natalizumab. ${ }^{3}$

While HAART has a significant beneficial impact on the prognosis of PML in patients with HIV, it remains one of the 4 most common CNS opportunistic infections affecting patients with AIDS. ${ }^{4}$ The institution of screening patients with MS for seropositivity for JC virus has decreased the prevalence of PML in natalizumab-treated patients with MS. The termination of this therapy and using plasma exchange to remove the monoclonal antibody from the circulation when PML is diagnosed has a beneficial effect on prognosis.

However, the introduction of HAART and the discontinuation of natalizumab led to the recognition of the immune reconstitution inflammatory syndrome (IRIS), an entity that is not unique to PML and has been observed also with mycobacterial diseases, leprosy, fungal infections, and herpes viruses. ${ }^{5}$ IRIS is the consequence of rapid entry of immune cells into the brain at the time of immune restoration. As many as $23 \%$ of patients with AIDS with PML who recently started HAART will develop PMLIRIS. ${ }^{6}$ IRIS has occurred in the majority of patients with natalizumab-associated PML following withdrawal of natalizumab and plasma exchange. The diagnosis of CNS-IRIS in patients with MS with natalizumab-associated PML can be challenging because the deterioration might be attributed to PML, MS, or some other opportunistic infection. ${ }^{7}$

Thus, diagnosis of PML in an immunecompromised patient is associated with a 2-edge challenge and risk: clearing the JC virus from the brain, which requires normalization of the immune state, and reconstitution of immune surveillance while minimizing infiltration of the brain with activated $\mathrm{T}$ cells that attempt to control an underlying CNS opportunistic infection.

Treatment of CNS-IRIS is mainly empirical; as of today, there are no randomized controlled trials to support antiviral or immune-modulating therapy in this condition. The suggestion to treat CNS-IRIS with steroids remains at present a hypothesis. ${ }^{8}$

In 2009, a case report on the use of maraviroc, a CCR5 antagonist that has been approved for the treatment of HIV infection to inhibit CCR5dependent viral docking in AIDS suggested that this agent might be effective against CNS-IRIS. ${ }^{9}$ The observation was not confirmed in a large study. ${ }^{10}$

Maraviroc is also associated with blocking of CCR5-mediated inflammation and was reported to be beneficial in graft-vs-host disease in patients undergoing allogenic bone marrow transplantation. ${ }^{11}$ It also decreases the amount of CD8 cells in the CNS of patients. ${ }^{12}$ This led to an effort to extrapolate the use of maraviroc to PML under monoclonal antibodies therapy for MS. ${ }^{12}$ This was associated with reduced trafficking of CCR5-expressing cells into 
the CSF and survival of the patient with relatively stable neurologic sequelae.

In this issue of Neurology: Neuroimmunology \& Neuroinflammation, 2 independent reports are published on 3 natalizumab-treated patients with MS with CNS-IRIS handled with maraviroc. ${ }^{13,14}$ In all 3 patients, the syndrome seems to benefit, in part, from the therapy, but use of steroids (in 2), avoidance of plasma exchange (in all), and young age (in 2) might have contributed to the outcome. Maraviroc is not an innocent compound and is associated with hepatotoxicity, infections, cancer, and cardiovascular disorders. ${ }^{15}$

The conflicting results on the outcome of IRIS in maraviroc-treated HIV-infected patients and natalizumab-treated patients with MS may suggest a different pathogenesis and/or mechanism of action of the antiviral agent. However, currently available information is too less to draw any conclusions.

To summarize, the available information on the potential of maraviroc in monoclonal antibodyassociated PML is too less to enable any recommendation. More anecdotal reports will eventually point to the possibility that a large phase II is warranted.

\section{STUDY FUNDING}

No targeted funding reported.

\section{DISCLOSURE}

I. Steiner served on the DSMB for Novartis and Actelion and on the editorial board for Journal of Neurovirology, Journal of Neurological Sciences, and Neurology: Neuroimmunology \& Neuroinflammation; received research support from Israel Science Foundation, Israel Ministry of Health Chief Scientist, and Teva NNE; and is an expert witness in legal cases involving patients involved in car accidents. F. Benninger received research support from Israeli Science Foundation. Go to Neurology.org/nn for full disclosure forms.

\section{REFERENCES}

1. Astrom KE, Mancall EL, Richardson EP Jr. Progressive multifocal leuko-encephalopathy; a hitherto unrecognized complication of chronic lymphatic leukaemia and Hodgkin's disease. Brain 1958;81:93-111.

2. Steiner I, Berger JR. Update on progressive multifocal leukoencephalopathy. Curr Neurol Neurosci Rep 2012; 12:680-686.
3. chefarztfraulicher: beobachter. Journal für Asymmetrische Polemic. Available at: https://chefarztfrau.de/. Accessed December 31, 2016.

4. Collazos J. Opportunistic infections of the CNS in patients with AIDS: diagnosis and management. CNS Drugs 2003;17:869-887.

5. Lawn SD, Meintjes G. Pathogenesis and prevention of immune reconstitution disease during antiretroviral therapy. Expert Rev Anti Infect Ther 2011;9:415-430.

6. Falcó V, Olmo M, del Saz SV, et al. Influence of HAART on the clinical course of HIV-1-infected patients with progressive multifocal leukoencephalopathy: results of an observational multicenter study. J Acquir Immune Defic Syndr 2008;49:26-31.

7. Steiner I. PML: underdiagnosed in MS patients on natalizumab. Lancet Neurol 2010;9:564.

8. Antoniol C, Jilek S, Schluep M, et al. Impairment of JCVspecific T-cell response by corticotherapy: effect on PMLIRIS management? Neurology 2012;79:2258-2264.

9. Martin-Blondel G, Cuzin L, Delobel P, et al. Is maraviroc beneficial in paradoxical progressive multifocal leukoencephalopathy-immune reconstitution inflammatory syndrome management? AIDS 2009;23:2545-2546.

10. Sierra-Madero JG, Ellenberg SS, Rassool MS, et al. Effect of the CCR5 antagonist maraviroc on the occurrence of immune reconstitution inflammatory syndrome in HIV (CADIRIS): a double-blind, randomised, placebocontrolled trial. Lancet HIV 2014;1:e60-e67.

11. Reshef R, Luger SM, Hexner EO, et al. Blockade of lymphocyte chemotaxis in visceral graft-versus-host disease. N Engl J Med 2012;367:135-145.

12. Giacomini PS, Rozenberg A, Metz I, Araujo D, Arbour N, Bar-Or A; Maraviroc in Multiple Sclerosis-Associated PML-IRIS (MIMSAPI) Group. Maraviroc and JC virusassociated immune reconstitution inflammatory syndrome. N Engl J Med 2014;370:486-488.

13. Hodecker SC, Stuerner KH, Becker V, et al. Maraviroc as possible treatment for PML-IRIS in natalizumab-treated multiple sclerosis patients. Neurol Neuroimmunol Neuroinflamm 2017;4:e325. doi: 10.1212/NXI.0000000000000325.

14. Bsteh G, Auer M, Iglseder S, Walchhofer LM, Dietmar Langenscheidt D, Stefan Koppi S, Schauer-Maurer G, Stockhammer G, Berger T. Severe early natalizumabassociated PML in MS: effective control of PML-IRIS with maraviroc. Neurol Neuroimmunol Neuroinflamm 2017;4:e323. doi: 10.1212/NXI.0000000000000323.

15. Woollard SM, Kanmogne GD. Maraviroc: a review of its use in HIV infection and beyond. Drug Des Devel Ther 2015;9:5447-5468. 


\title{
Neurology \\ Neuroimmunology \& Neuroinflammation
}

\author{
Maraviroc in PML-IRIS: A separate ball game under HIV infection and natalizumab? \\ Israel Steiner and Felix Benninger \\ Neurol Neuroimmunol Neuroinflamm 2017;4; \\ DOI 10.1212/NXI.0000000000000331
}

This information is current as of February 8, 2017

\section{Updated Information \& Services}

References

Subspecialty Collections

Permissions \& Licensing

Reprints including high resolution figures, can be found at:

http://nn.neurology.org/content/4/2/e331.full.html

This article cites 14 articles, 0 of which you can access for free at: http://nn.neurology.org/content/4/2/e331.full.html\#\#ref-list-1

This article, along with others on similar topics, appears in the following collection(s):

Multiple sclerosis

http://nn.neurology.org//cgi/collection/multiple_sclerosis

Information about reproducing this article in parts (figures,tables) or in its entirety can be found online at:

http://nn.neurology.org/misc/about.xhtml\#permissions

Information about ordering reprints can be found online: http://nn.neurology.org/misc/addir.xhtml\#reprintsus

Neurol Neuroimmunol Neuroinflamm is an official journal of the American Academy of Neurology.

Published since April 2014, it is an open-access, online-only, continuous publication journal. Copyright

Copyright $\odot 2017$ The Author(s). Published by Wolters Kluwer Health, Inc. on behalf of the American

Academy of Neurology. All rights reserved. Online ISSN: 2332-7812.

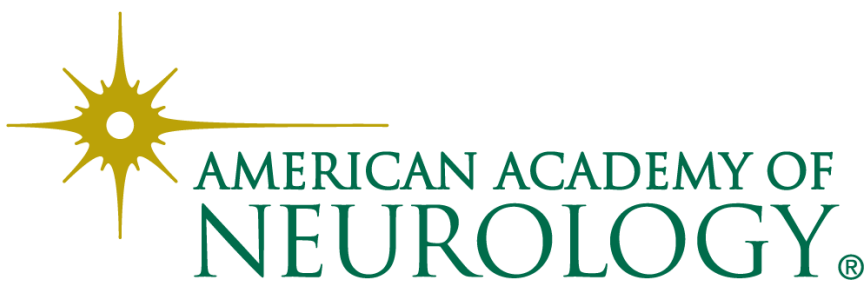

